Proceedings

\title{
Biogeographic Distribution of Cedrela spp. Genus in Peru Using MaxEnt Modeling: A Conservation Approach ${ }^{\dagger}$
}

\author{
Dany A. Cotrina Sánchez ${ }^{1, *}$, Nilton B. Rojas Briceño ${ }^{1}$ and Subhajit Bandopadhyay ${ }^{2}$ \\ 1 Instituto de Investigación para el Desarrollo Sustentable de Ceja de Selva (INDES-CES) de la, Universidad \\ Nacional Toribio Rodríguez de Mendoza de Amazonas, Chachapoyas 01001, Peru; \\ nrojas@indes-ces.edu.pe \\ 2 Department of Ecology and Environmental Protection, Poznan University of Life Sciences, Piatkowska 94, \\ 60-649 Poznan, Poland; subhajit.bandopadhyay@up.poznan.pl \\ * Correspondence: alexander.cotrina@untrm.edu.pe; Tel.: +51-976-010-315 \\ † Presented at the 1st International Electronic Conference on Biological Diversity, Ecology and Evolution, 15- \\ 31 March 2021; Available online: https://bdee2021.sciforum.net/.
}

Citation: Cotrina Sánchez, D.A.; Rojas Briceño, N.B.; Bandopadhyay, S. Biogeographic Distribution of Cedrela spp. Genus in Peru Using MaxEnt Modeling: A Conservation Approach. Proceedings 2021, 68, x. https://doi.org/10.3390/xxxxx

Academic Editor

Published: date

Publisher's Note: MDPI stays neutral with regard to jurisdictional claims in published maps and institutional affiliations.

Copyright: $₫ 2021$ by the authors. Submitted for possible open access publication under the terms and conditions of the Creative Commons Attribution (CC BY) license (http://creativecommons.org/licenses/by/4.0/).

\begin{abstract}
Expansion of croplands and livestock activities over the time have been considered as major driver for deforestration in Peru. Such severe deforestration activities significantly reduced the number of timber species particularly the genus Cedrela spp. that have high economic and ecological value in current time. Recently Cedrela spp. has been incorporated (28 August 2020) into appendix II of the Convention on International Trade in Endangered Species of Wild Fauna and Flora (CITES), a group of species that could be in danger in near-future. Considering this value, we modelled the biogeographic distribution of 10 species of the genus Cedrela (i.e., C. odorata, C. montana, C. fissilis, C. longipetiolulata, C. angustifolia, C. nebulosa, C. kuelapensis, C. Saltensis, C. weberbaueri and C. molinensis) with the objective to identify if the area legally protected by Protected Natural Areas (PNA), and prioritizing research and conservation/restoration areas of this particular genus. In this regard, 33 different environmental variables were used (19 bioclimatic variables, 3 topographic, 9 edaphic, solar radiation and relative humidity) throughout Peruvian Amazon using a maximum entropy model (MaxEnt). It was observed that $6.67 \%\left(86,235.24 \mathrm{~km}^{2}\right)$ of the Peruvian territory presents a high probability of distribution of the evaluated species and whereas the PNA protects only $4.42 \%\left(8363.09 \mathrm{~km}^{2}\right)$ of the territory that covers genus Cedrela. Furthermore, we have identified that $11.65 \%\left(21,345.16 \mathrm{~km}^{2}\right)$ of the area have highly prone to degradation for genus Cedrela that needs urgent attention for protection and restoration. We believe that this study will contribute as a tool for the processes of conservation of threatened species, conservation of biodiversity, management and sustainable use of forest resources.
\end{abstract}

Keywords: Cedrela; MaxEnt; conservation; Peru; amazon

\section{Introduction}

Forest covers have been reduced drastically as a result of agricultural expansion and livestock activities, deforestation, mining, urban expansion, in the Peruvian amazon over last decades [1,2]. In Peru 2433314 ha of Amazonian forests have been lost during 20012019 [3]. Although the Amazon cover covers 60\% of Peru [4], it has been fragmented by forest harvesting activities, a direct cause of deforestation, and indirectly promotes migratory agriculture [5], by eliminating the forest cover of approximately 0.5 ha for crop production [6,7]. Additionally, the selective falling of trees, mainly of species of high economic value, has caused the near extinction of species such as mahogany (Swietenia macrophylla) and cedar (Cedrela odorata) [8].

Cedrela spp. is a genus of tropical trees that includes species such as C. odorata L. and C. fissilis Vell., and that have been collected for wood for more than 500 years in Central 
and South America, with C. odorata being the second most demanded tropical wood [9-12]. Due to the high value of the species of the genus Cedrela spp., their use has increased since the end of the 1980s, mainly in Mexico, Brazil, Peru and Bolivia $[13,14]$. This trend has led to the collapse of the populations of Cedrela spp. due to overexploitation, but it has also led the international conservation community to call for greater protection under the Convention on International Trade in Endangered Species of Wild Fauna and Flora (CITES). In Peru, the National Forest and Wildlife Service (SERFOR), incorporated as of August 28, 2020, the populations of the genus Cedrela spp. (C. odorata, C. montana, $C$. fissilis, C. longipetiolulata, C. angustifolia, C. nebulosa, C. kuelapensis, C. Saltensis, C. weberbaueri and C. molinensis) of Appendix II of CITES. The main objective of this study is to identify the spatio-temporal distribution of Cedrela spp. in the perspective ofconservation and sustainable use of this particular species [15].

This reality suggests the need to develop studies that contribute to decision-making in relation to the sustainability and conservation of the biodiversity of Cedrela spp. and its habitat. Species distribution models (SDM) are tools that combine species presence data with bioclimatic, edaphic, topographic factors, etc. and allow a more effective and generous support for conservation, biogeography, evolution and climate change actions [16-20]. The SDMs have made it possible to identify the distribution of timber forest species on a regional scale [21,22], conservation of endemic species [23], wildlife [24,25], in order to intervene in areas to protect and identify the distribution of tree species in danger of extinction [26,27]. Among the SDMs, the maximum entropy algorithm (MaxEnt) [28], has been used to carry out the distribution of species under current and future conditions $[29,30]$. In this way, MaxEnt allows habitat mapping and produce credible, defensible and repeatable information, which contributes to a structured and transparent process of sustainable management of natural resources by predicting the possible fragmentation or reduction of the potential area of forests or species in risk under future climate change scenarios [31].

From the identification of the potential distribution areas of a species, the areas with the best aptitude to carry out reforestation or recovery of degraded areas with the evaluated species need to be quantified and monitored. Restoration is of great interest since $13.78 \%\left(177592.82 \mathrm{~km}^{2}\right)$ of the Peruvian territory has been identified as degraded, as a consequence of deforestation, livestock, agriculture, mining, forest fires, among others [32]. The strategies to be implemented must be oriented to the restoration and/or conservation of threatened species that are widely distributed in geographic spaces integrated into the territorial order, through the use of environmental services, ecotourism, management of renewable resources and productive practices promoting through the Protected Natural Areas (PNA) [33].

This study modeled the potential distribution of 10 species of the genus Cedrela (i.e., C. odorata, C. montana, C. fissilis, C. longipetiolulata, C. angustifolia, C. nebulosa, C. kuelapensis, C. Saltensis, C. weberbaueri and C. molinensis) through MaxEnt model, using the data on the presence of the species and 33 different variables (19 bioclimatic variables, 3 topographic, 9 edaphic, solar radiation and relative humidity), identifying the distribution within PNA and areas degraded for forest recovery and conservation of natural resources in the Peruvian territory.

\section{Study Area}

This study covers the entire territory of Peru (1.300.000 $\mathrm{km}^{2}$ Aprox.), considering the Natural Protected Areas (PNAs) (Figure 1) belonging to the National System of Natural Areas Protected by the State (SINPNAE) (SINANPE) [33] and the degraded areas areas identified by the Ministry of the Environment of Peru [32]. 


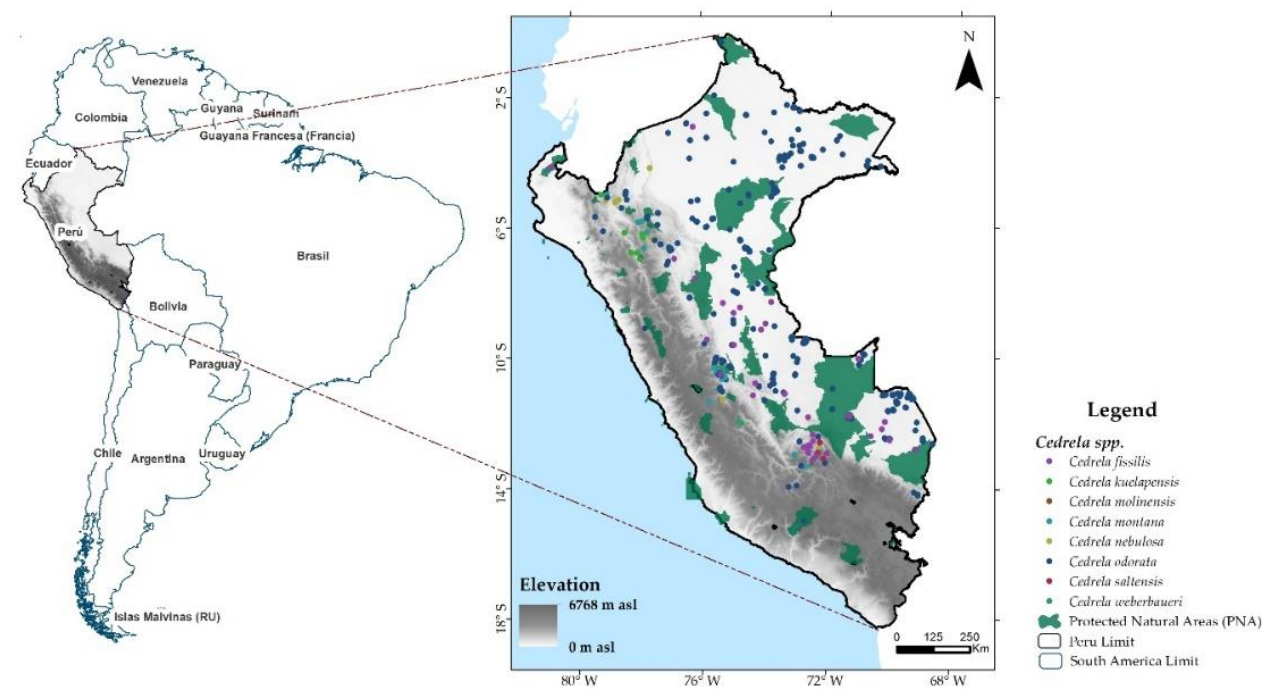

Figure 1. Study area and presence of Cedrela spp. species.

\section{Materials and Methods}

\subsection{Datase}

The presence data (geographic coordinates) of the 10 species of the genus Cedrela spp. were obtained from the GBIF Global Biodiversity Information Service (https://www.gbif.org/), through the Species Explorer plugin in QGIS. The data were filtered at a spatial resolution of $250 \mathrm{~m}$ [34] exported in CSV format to be used in the MaxEnt program.

33 variables were selected (Table 1 ) to carry out the modeling. These variables include 19 bioclimatic and solar radiation obtained from WorldClim 2.1 (https://www.worldclim.org/) [35]; 3 topographic derived from digital elevation model (DEM), obtained from the United States Geological Survey (USGS) web portal (http://srtm.usgs.gov); the relative humidity obtained from the Climate Research Unit (CRU) [36] (www.cru.uea.ac.uk) and 9 soil properties from SoilGrids 0.5.3 (http://soilgrids.org) [37]. All variables were rescaled to a spatial resolution of $250 \mathrm{~m}$. to overcome the issues like collinearity between variables causes overfitting problems, increases uncertainty and decreases the statistical power of the model [38]. Therefore, using the function 'removeCollinearity' from the package 'virtualspecies' [39] in R 3.6, the variables were grouped (clustering) according to a Pearson correlation coefficient and considered those have the Pearson's $r \geq 0.7$. This threshold is an acceptable measure to minimize multicollinearity of fitted models [38]. To select an important variable for each cluster, a preliminary MaxEnt model was run (the configuration is explained in Section 3.2.) Using all the variables and the variable with the best performance in the Jackknife test [25] was selected (that is, the smallest difference in regularized training gains obtained from a model generated with all criteria except that of interest and a model generated only with the criterion of interest [21], Table 1).

Table 1. Variables for MaxEnt modeling of Cedrela spp. in Peru.

\begin{tabular}{ccccc}
\hline Variable & Units & Symbol & D Earnings in Jackknife ${ }^{1}$ & Clúster \\
\hline & Bioclimatic & & & \\
\hline Annual Mean Temperature & ${ }^{\circ} \mathrm{C}$ & bio01 & 0.7379 & 1 \\
Mean Diurnal Range & ${ }^{\circ} \mathrm{C}$ & bio02 & 0.7627 & 7 \\
Isothermality & & bio03 & 0.9150 & 4 \\
Temperature Seasonality & ${ }^{\circ} \mathrm{C}$ & bio04 & $\mathbf{0 . 7 0 9 7}$ & $\mathbf{9}$ \\
Max Temperature of Warmest Month & ${ }^{\circ} \mathrm{C}$ & bio05 & 0.6811 & 1 \\
Min Temperature of Coldest Month & ${ }^{\circ} \mathrm{C}$ & bio06 & 0.7068 & 1
\end{tabular}


Annual Temperature Range Mean Temperature of Wettest Quarter Mean Temperature of Driest Quarter Mean Temperature of Warmest Quarter Mean Temperature of Coldest Quarter Annual Precipitation

Precipitation of Wettest Month Precipitation of Driest Month Precipitation Seasonality

Precipitation of Wettest Quarter

Precipitation of Driest Quarter

Precipitation of Warmest Quarter

Precipitation of Coldest Quarter

$\begin{array}{cccc}{ }^{\circ} \mathrm{C} & \text { bio07 } & 0.7655 & 9 \\ { }^{\circ} \mathrm{C} & \text { bio08 } & 0.7608 & 1 \\ { }^{\circ} \mathrm{C} & \text { bio09 } & 0.7107 & 1 \\ { }^{\circ} \mathrm{C} & \text { bio10 } & 0.7606 & 1 \\ { }^{\circ} \mathrm{C} & \text { bio11 } & 0.7067 & 1 \\ \mathrm{~mm} & \text { bio12 } & \mathbf{0 . 6 2 3 1} & \mathbf{3} \\ \mathrm{mm} & \text { bio13 } & 0.7674 & 2 \\ \mathrm{~mm} & \text { bio14 } & 0.5525 & 3 \\ \mathrm{~mm} & \text { bio15 } & 0.6692 & 9 \\ \mathrm{~mm} & \text { bio16 } & 0.7524 & 2 \\ \mathrm{~mm} & \text { bio17 } & 0.5481 & 3 \\ \mathrm{~mm} & \text { bio18 } & 0.7915 & 2 \\ \mathrm{~mm} & \text { bio19 } & \mathbf{0 . 5 1 4 7} & 3\end{array}$

\begin{tabular}{|c|c|c|c|c|}
\hline \multicolumn{5}{|c|}{ Topographic } \\
\hline Elevation above mean sea level & msnm & dem & 0.6709 & 7 \\
\hline Slope of the terrain & $\circ$ & slope & 0.9104 & 7 \\
\hline Cardinal orientation of the slope & $\circ$ & aspect & 1.0117 & 5 \\
\hline \multicolumn{5}{|c|}{ Edáficas } \\
\hline $\mathrm{pH}$ in $\mathrm{H}_{2} \mathrm{O}$ a $0.30 \mathrm{~m}$ & $\mathrm{pHx10}$ & ph & 0.6543 & 7 \\
\hline Cation exchange capacity at $0.30 \mathrm{~m}$ & $\mathrm{cmol} \mathrm{kg-1}^{-1}$ & cec & 0.7898 & 6 \\
\hline Organic carbon at $0.30 \mathrm{~m}$ & $\mathrm{~g} \mathrm{~kg}^{-1}$ & soc & 0.8094 & 4 \\
\hline Apparent density of the fine earth fraction & $\mathrm{cg} / \mathrm{cm}^{3}$ & bdod & 0.8881 & 8 \\
\hline Volumetric fraction of coarse fragments & $\mathrm{cm}^{3} / \mathrm{dm}^{3}(\mathrm{vol} \%$ o $)$ & cfvo & 0.7051 & 7 \\
\hline Total nitrogen & $\mathrm{cg} / \mathrm{kg}$ & nitrogen & 0.8375 & 6 \\
\hline Clay content & $\%$ & clay & 0.8743 & 4 \\
\hline Sand content & $\%$ & sand & 0.8155 & 7 \\
\hline Slime content & $\%$ & silt & 0.7970 & 2 \\
\hline Solar radiation & MJ m ${ }^{-2}$ day $^{-1}$ & srad & 0.6801 & 9 \\
\hline Relative humidity & $\%$ & rhm & 0.7777 & 3 \\
\hline
\end{tabular}

${ }^{1}$ In bold, the variables with less variation between the regularized training win without the variable and with only the variable for each cluster, and that therefore was used in the final MaxEnt model.

\subsection{Methods}

The biogeographic distribution model for the 10 species of the genus Cedrela spp. was performed using a maximum entropy algorithm [28], which estimates the probability of potential distribution of each species from the presence data, using the open source software MaxEnt ver. 3.4.1 (https://biodiversityinformatics.amnh.org/open_source/maxent/). For the validation of the model, randomly selected presence data were used, $75 \%$ for training and $25 \%$ for validation respectively [28]. The algorithm was run using 100 repetitions in 5000 iterations with different random partitions (Bootstrap method), other configurations (i.e., extrapolation, graph drawing, etc.) were kept by default [40].

The resulting model was validated based on the area under the curve (AUC), calculated from the operating characteristic of the receptor (ROC) [28,41,42]. According to the AUC values, five performance levels are differentiated: excellent $(>0.9)$, good $(0.8-0.9)$, accepted $(0.7-0.8)$, poor $(0.6-0.7)$ and invalid $(<0.6)[41,43]$. We have used the logistic output format to obtain the model of the 10 species evaluated, by generating a raster of continuous values in a range from 0 to 1 . The raster obtained was reclassified into four ranges: (1) "High potential" habitat (>0.6), (2) "moderate" habitat (0.4-0.6), (3) "low" habitat (0.2$0.4)$ and (4) "no potential" habitat $(<0.2)[21,22,25,44]$.

Subsequently, the areas of "high" distribution potential were overlapped with the Protected Natural Areas (PNA) [33], obtained from the geoserver (https://geo.sernPNA.gob.pe/visorsernPNA/) of the National Service of Natural Areas 
protected by the State (SERNPNA) and in the same way with the degraded areas identified by the Ministry of the Environment of Peru (MINAM) and available on its geoserver (https://geoservidor.minam.gob.pe/) [32]. Finally, the distribution surface of the 10 species within the PNA and degraded areas were quantified.

\section{Result and Discussion}

\subsection{Result}

The performance of the model obtained an AUC $=0.866$ (Figure 2b), considered good $(0.8<$ AUC $<0.9)$. Likewise, the Jackknife test (Figure 2a) Obtained identified that the variables Bio 19 (coldest quarter precipitation), Bio 12 (annual precipitation), pH and soil elevation (DEM) contributed highly in the biogeographic distribution model of the species.

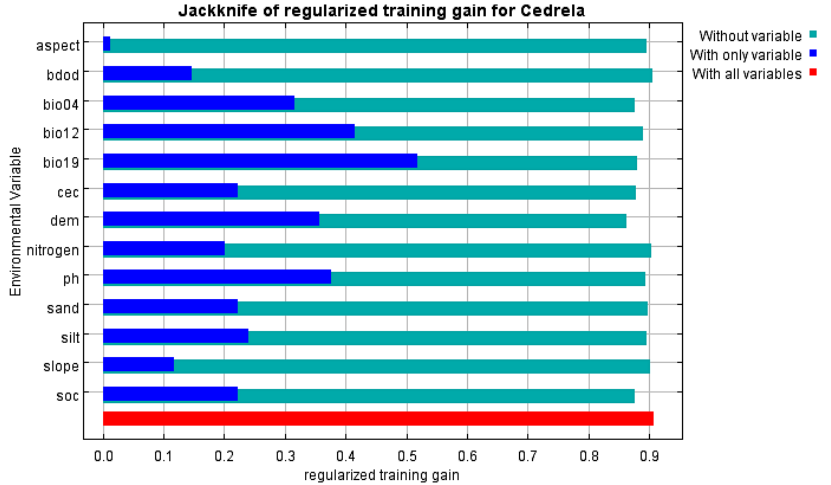

(a)

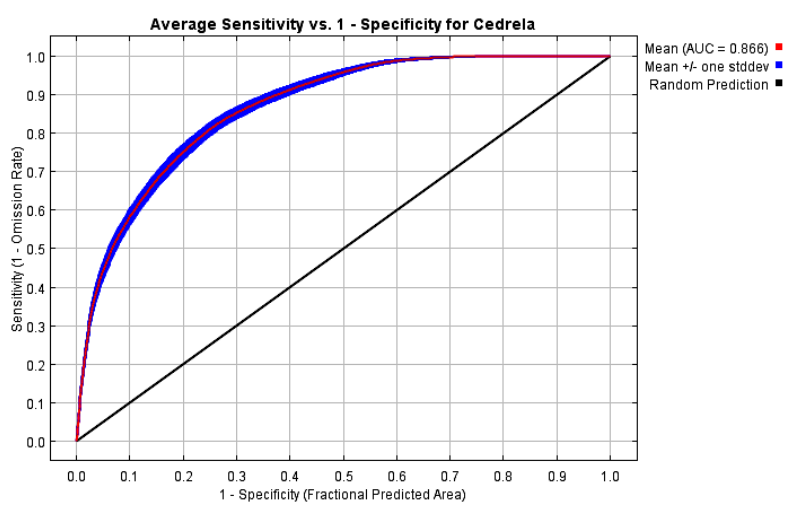

(b)

Figure 2. Jackknife performance of variables and Area Under the Curve (AUC).

The high biogeographic distribution of the 10 species of the genus Cedrela spp. cover $6.67 \%\left(86,235.24 \mathrm{~km}^{2}\right.$ ) of the Peruvian territory (Figure 3a), of which the PNA cover $4.42 \%$ $\left(8363.09 \mathrm{~km}^{2}\right)$ of said distribution (Figure $3 \mathrm{~b}$ ). Likewise, there was a potential for recovery of degraded areas in an area of $11.65 \%\left(21,345.16 \mathrm{~km}^{2}\right)$ with the species evaluated (Figure 3c).
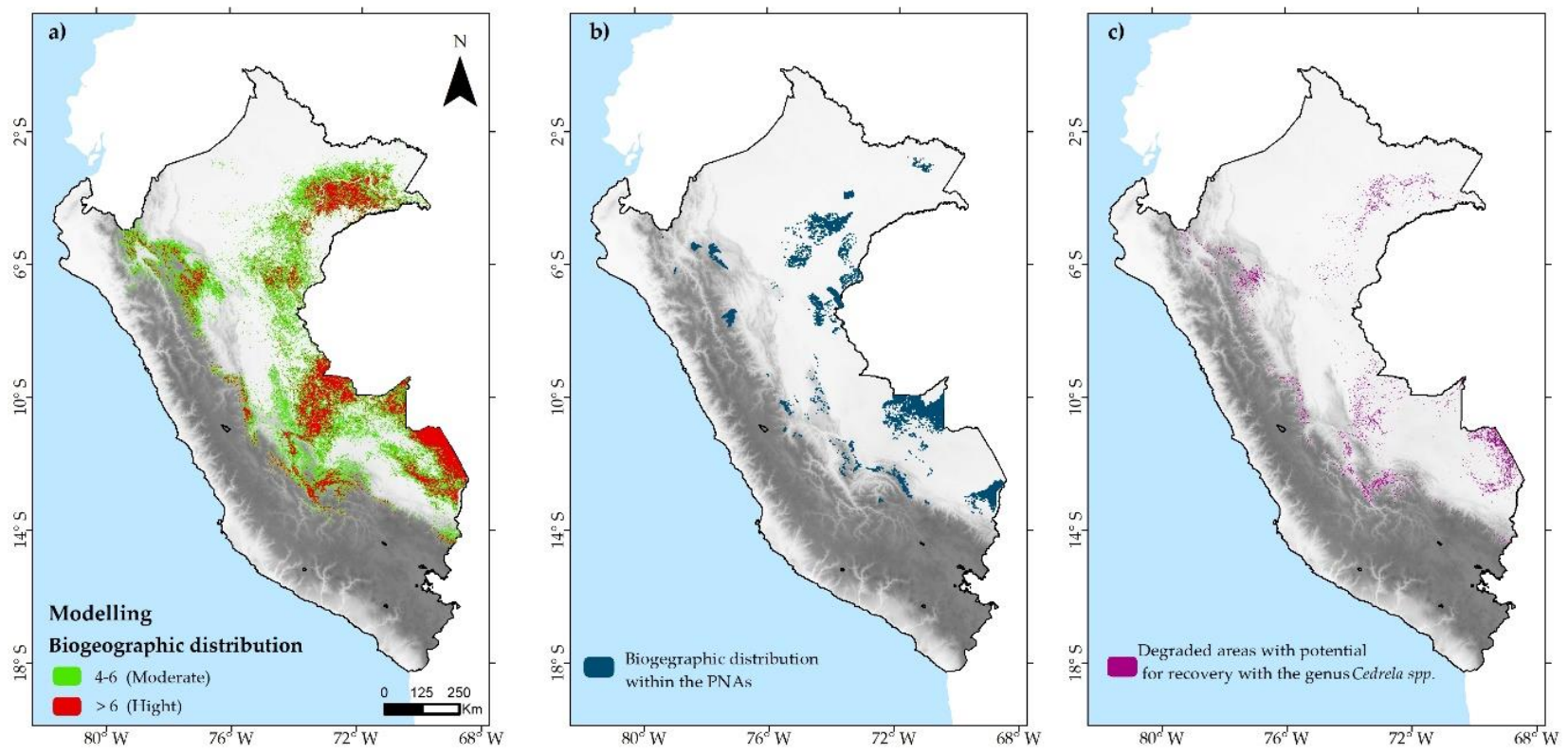

Figure 3. Distribution of the biographical model of the genus Cedrela spp., distribution of PNA and in degraded areas for recovery. 


\subsection{Discussion}

This study graphs the biogeographic distribution of 10 species of the genus Cedrela spp. (C. odorata, C. montana, C. fissilis, C. longipetiolulata, C. angustifolia, C. nebulosa, C. kuelapensis, C. Saltensis, C. weberbaueri and C. molinensis) also identified the spatio-temporal distribution, which will allow the establishment of forest management strategies [45], mainly for the species of high economic value that have been reduced by selective logging and overexploitation [8,11,14,15].

This study showed that MaxEnt based SDM tools that will allow the identification and prediction of geographic spaces with edaphoclimatic, topographic, equal or similar characteristics of the presence data [46]. Previous studies have used MaxEnt, this being the most accepted [47] and was related to the distribution of timber species at the regional $[21,22]$, national [48-50] level and the identification of niches ecological for C. odorata in Peru [51].

Our model obtained a performance considered good $(\mathrm{AUC}=0.866)[28,41,43,52]$, where the variables Bio 19 (precipitation of the coldest room), Bio 12 (annual precipitation), $\mathrm{pH}$ and soil elevation (DEM) present a greater contribution independently in the model. Therefore, as in this study, it is recommended to use climatic and edaphic variables in the species distribution modeling [53], considering that altitude was also a determining factor in the distribution ranges of a species [21,22]. Likewise, our results were in agreement with the location of the botanical collections and inventories of the evaluated species $[12,49,50]$. This will help the local stack holders to knowing the distribution of a indengered species and implement strategies that allow the conservation of biodiversity, in one of the most megadiverse countries in the world such as Peru [54,55].

The PNAs play a fundamental role in the conservation and protection of biodiversity [56], so that $4.42 \%$ of the PNAs in Peru contains the genus Cedrela which highlights the importance of protecting these vulnerable species which were usually the most threatened [55]. Likewise, there are degraded areas [32] with the potential to be recovered with the Cedrela species whereas $11.65 \%$ of the Peruvian territory, promoting the practice of forest restoration to maintain natural ecosystems, through the installation of enrichment plantations, regeneration natural management, agroforestry systems and silvicultural practices for the regeneration of degraded forests [4,57-59].

\section{Conclusions}

The biogeographic model of the 10 species of the genus Cedrela spp. (C. odorata, $C$. montana, C. fissilis, C. longipetiolulata, C. angustifolia, C. nebulosa, C. kuelapensis, C. Saltensis, C. weberbaueri and C. molinensis) using MaxEnt obtained a good performance, with an AUC of 0.866 . Our model has a high distribution in the Peruvian territory, coveringc $6.67 \%$ $\left(86,235.24 \mathrm{~km}^{2}\right)$ of the surface. Likewise, contemplates that the potential distribution of the 10 species were distributed within these areas in an area of $8363.09 \mathrm{~km}^{2}$ in $4.42 \%$ of its protected territory. Finally, our study identified that $11.65 \%\left(21,345.16 \mathrm{~km}^{2}\right)$ of the areas identified as degraded present conditions to be recovered with one or more types of species under study. This study will allow to restrore many ecosystem functions and recovering many components of biodiversity in an original form.

Author Contributions: Conceptualization, D.A.C.S. and N.B.R.B.; Data curation, D.A.C.S.; Formal analysis, D.A.C.S., N.B.R.B. and S.B.; Investigation, D.A.C.S., N.B.R.B. and S.B.; Methodology, D.A.C.S. and N.B.R.B.; Software, D.A.C.S. and N.B.R.B.; Supervision, S.B.; Writing - original draft, D.A.C.S.; Writing - review and editing, D.A.C.S., N.B.R.B. and S.B. All authors have read and agreed to the published version of the manuscript.

Institutional Review Board Statement:

Informed Consent Statement:

Data Availability Statement: 
Acknowledgments: The authors appreciate and acknowledge the support of the Research Institute for the Sustainable Development of the Eyebrow of the Jungle (INDES-CES) of the National University Toribio Rodriguez de Amazonas (UNTRM).

Conflicts of Interest: The authors declare no conflict of interest.

\section{References}

1. Bruun, T.B.; Elberling, B.; de Neergaard, A.; Magid, J. Organic carbon dynamics in different soil types after conversion of forest to agriculture. L. Degrad. Dev. 2013, 26, 272-283, doi:10.1002/ldr.2205.

2. Sánchez-Cuervo, A.M.; de Lima, L.S.; Dallmeier, F.; Garate, P.; Bravo, A.; Vanthomme, H. Twenty years of land cover change in the southeastern Peruvian Amazon: Implications for biodiversity conservation. Reg. Environ. Chang. 2020, 20, doi:10.1007/s10113-020-01603-y.

3. GeoBosques Bosque y Pérdida de Bosque. Available online: http://geobosques.minam.gob.pe/geobosque/view/perdida.php (accessed on 10 February 2021).

4. Flores, Y. Crecimiento y Productividad de Plantaciones Forestales en la Amazonía Peruana; Perú, 2010.

5. Dourojeanni, R.M. Aprovechamiento del barbecho forestal en áreas de agricultura migratoria en la Amazonía peruana. Rev. For. del Perú 2016, 14, 1-33, doi:10.21704/rfp.v14i2.136.

6. Suárez de Freitas, G. Reducción de la Deforestación (Principalmente en la AMAZONÍA) en el Contexto del Cambio Climático y de un Enfoque de Crecimiento Verde; Lima, Peru, 2017.

7. Marquardt, K.; Pain, A.; Bartholdson, Ö.; Rengifo, L.R. Forest Dynamics in the Peruvian Amazon: Understanding Processes of Change. Small-scale For. 2019, 18, 81-104, doi:10.1007/s11842-018-9408-3.

8. Escobal, J.; Aldana, U. Are nontimber forest products the antidote to rainforest degradation? Brazil nut extraction in Madre De Dios, Peru. World Dev. 2003, 31, 1873-1887, doi:10.1016/j.worlddev.2003.08.001.

9. Lamb, A.F.A. Fast Growing Timber trees of the Lowland Tropics. Cedrela Odorata. Oxford Forestry Institute: Oxford, UK, 1968; p. 58.

10. Cintrón, B.B. Meliaceae Familia de la Caoba; 1990; pp. 128-134.

11. Navarro, C.; Montagnini, F.; Hernández, G. Genetic variability of Cedrela odorata Linnaeus: Results of early performance of provenances and families from Mesoamerica grown in association with coffee. For. Ecol. Manage. 2004, 192, 217-227, doi:10.1016/j.foreco.2004.01.037.

12. Pennington, T.D.; Muellner, A.N.; Wise, R. A Monograph of Cedrela (Meliaceae); 2010; ISBN 0953813479.

13. Rosser, A.; Haywood, M. Guidance for CITES Scientific Authorities; 2002.

14. Cerrillo, R.M.N.; Agote, N.; Pizarro, F.; Ceacero, C.J.; Palacios, G. Elements for a non-detriment finding of Cedrela spp. in BoliviaA CITES implementation case study. J. Nat. Conserv. 2013, 21, 241-252, doi:10.1016/j.jnc.2013.01.003.

15. SERFOR. Resolución de Dirección Ejecutiva No D000067-2020-MINAGRI-SERFOR-DE; Perú, 2020; pp. 1-3.

16. Guisan, A.; Tingley, R.; Baumgartner, J.B.; Naujokaitis-Lewis, I.; Sutcliffe, P.R.; Tulloch, A.I.T.; Regan, T.J.; Brotons, L.; Mcdonald-Madden, E.; Mantyka-Pringle, C.; et al. Predicting species distributions for conservation decisions. Ecol. Lett. 2013, 16, 1424-1435, doi:10.1111/ele.12189.

17. Fagundes, C.K.; Vogt, R.C.; De Marco Júnior, P. Testing the efficiency of protected areas in the Amazon for conserving freshwater turtles. Divers. Distrib. 2016, 22, 123-135, doi:10.1111/ddi.12396.

18. Guisan, A.; Zimmermann, N.E. Predictive Habitat Distribution Models in Ecology. Ecol. Model. 2000, 135, 147-186, doi:10.1016/S0304-3800(00)00354-9.

19. Guisan, A.; Thuiller, W. Predicting species distribution: Offering more than simple habitat models. Ecol. Lett. 2005, 8, 993-1009, doi:10.1111/j.1461-0248.2005.00792.x.

20. Peterson, A.T.; Soberón, J.; Pearson, R.G.; Anderson, R.P.; Martínez-Meyer, E.; Nakamura, M.; Araújo, M.B. Ecological Niches and Geographic Distributions (MPB-49); 2011; ISBN 9780691136868.

21. Cotrina, D.A.; Castillo, E.B.; Rojas, N.B.; Oliva, M.; Guzman, C.T.; Amasifuen, C.A.; Bandopadhyay, S. Distribution models of timber species for forest conservation and restoration in the Andean-Amazonian landscape, North of Peru. Sustainability 2020, 12, 7945, doi:10.3390/su12197945.

22. Rojas, N.B.; Cotrina, D.A.; Castillo, E.B.; Oliva, M.; Salas, R. Current and Future Distribution of Five Timber Forest Species in Amazonas , Northeast Peru : Contributions towards a Restoration Strategy. Diversity 2020, 12, 305, doi:10.3390/d12080305.

23. Abdelaal, M.; Fois, M.; Fenu, G.; Bacchetta, G. Using MaxEnt modeling to predict the potential distribution of the endemic plant Rosa arabica Crép. in Egypt. Ecol. Inform. 2019, 50, 68-75, doi:10.1016/j.ecoinf.2019.01.003.

24. Naveda-Rodríguez, A.; Vargas, F.H.; Kohn, S.; Zapata-Ríos, G. Andean Condor (Vultur gryphus) in Ecuador: Geographic Distribution, Population Size and Extinction Risk. PLoS ONE 2016, 11, e0151827, doi:10.1371/journal.pone.0151827.

25. Meza, G.; Castillo, E.B.; Guzmán, C.T.; Cotrina, D.A.; Guzman, B.K.; Oliva, M.; Bandopadhyay, S.; Salas, R.; Rojas, N.B. Predictive modelling of current and future potential distribution of the spectacled bear (Tremarctos ornatus) in Amazonas, northeast Peru. Animals 2020, 10, 1816, doi:10.3390/ani10101816.

26. Gilani, H.; Arif Goheer, M.; Ahmad, H.; Hussain, K. Under predicted climate change: Distribution and ecological niche modelling of six native tree species in Gilgit-Baltistan, Pakistan. Ecol. Indic. 2020, 111, 106049, doi:10.1016/j.ecolind.2019.106049. 
27. Qin, A.; Liu, B.; Guo, Q.; Bussmann, R.W.; Ma, F.; Jian, Z.; Xu, G.; Pei, S. Maxent modeling for predicting impacts of climate change on the potential distribution of Thuja sutchuenensis Franch., an extremely endangered conifer from southwestern China. Glob. Ecol. Conserv. 2017, 10, 139-146, doi:10.1016/j.gecco.2017.02.004.

28. Phillips, S.B.; Aneja, V.P.; Kang, D.; Arya, S.P. Maximum entropy modeling of species geographic distributions. Ecol. Model. 2006, 6, 231-252, doi:10.1016/j.ecolmodel.2005.03.026.

29. Hernandez, P.A.; Graham, C.H.; Master, L.L.; Albert, D.L. The effect of sample size and species characteristics on performance of different species distribution modeling methods. Ecography Cop. 2006, 29, 773-785, doi:10.1111/j.0906-7590.2006.04700.x.

30. Aguirre-Gutiérrez, J.; Carvalheiro, L.G.; Polce, C.; van Loon, E.E.; Raes, N.; Reemer, M.; Biesmeijer, J.C. Fit-for-Purpose: Species Distribution Model Performance Depends on Evaluation Criteria-Dutch Hoverflies as a Case Study. PLoS ONE 2013, 8, doi:10.1371/journal.pone.0063708.

31. Sofaer, H.R.; Jarnevich, C.S.; Pearse, I.S.; Smyth, R.L.; Auer, S.; Cook, G.L.; Edwards, T.C.; Guala, G.F.; Howard, T.G.; Morisette, J.T.; et al. Development and Delivery of Species Distribution Models to Inform Decision-Making. Bioscience 2019, 69, 544-557, doi:10.1093/biosci/biz045.

32. MINAM. Estudio para la Identificación de Áreas Degradadas y Propuesta de Monitoreo; Lima, Peru, 2017.

33. MINAM-SERNANP. Áreas Naturales Protegidas Del Perú (2011-2015)_Conservación para el Desarrollo Sostenible; $2016 ;$ Volume 1.

34. Boria, R.A.; Olson, L.E.; Goodman, S.M.; Anderson, R.P. Spatial filtering to reduce sampling bias can improve the performance of ecological niche models. Ecol. Modell. 2014, 275, 73-77, doi:10.1016/j.ecolmodel.2013.12.012.

35. Fick, S.E.; Hijmans, R.J. WorldClim 2: New 1-km spatial resolution climate surfaces for global land areas. Int. J. Climatol. 2017, 37, 4302-4315, doi:10.1002/joc.5086.

36. New, M.; Lister, D.; Hulme, M.; Makin, I. A high-resolution data set of surface climate over global land areas. Clim. Res. 2002, 21, 1-25, doi:10.3354/cr021001.

37. Hengl, T.; De Jesus, J.M.; Heuvelink, G.B.M.; Gonzalez, M.R.; Kilibarda, M.; Blagotić, A.; Shangguan, W.; Wright, M.N.; Geng, X.; Bauer-Marschallinger, B.; et al. SoilGrids250m: Global gridded soil information based on machine learning. PLoS ONE 2017, 12, doi:10.1371/journal.pone.0169748.

38. Dormann, C.F.; Elith, J.; Bacher, S.; Buchmann, C.; Carl, G.; Carré, G.; Marquéz, J.R.G.; Gruber, B.; Lafourcade, B.; Leitão, P.J.; et al. Collinearity: A review of methods to deal with it and a simulation study evaluating their performance. Ecography Cop. 2013, 36, 027-046, doi:10.1111/j.1600-0587.2012.07348.x.

39. Leroy, B.; Meynard, C.N.; Bellard, C.; Courchamp, F. Virtualspecies, an R package to generate virtual species distributions. Ecography Cop. 2016, 39, 599-607, doi:10.1111/ecog.01388.

40. Otieno, B.A.; Nahrung, H.F.; Steinbauer, M.J. Where did you come from? Where did you go? Investigating the origin of invasive Leptocybe species using distribution modelling. Forests 2019, 10, 115, doi:10.3390/f10020115.

41. Manel, S.; Williams, C.; Ormerod, S.J. Evaluating presence-Absence models in ecology : The need to account for prevalence. J. Appl. Ecol. 2001, 38, 921-931, doi:10.1046/j.1365-2664.2001.00647.x.

42. Hanley, J.A.; McNeil, B.J. The Meaning and Use of the Area under a Receiver Operating Characteristic (ROC) Curve1. Radiology 1982, 143, 29-36, doi:10.1148/radiology.143.1.7063747.

43. Araujo, M.; Pearson, R.; Thuiller, W.; Erhard, M. Validation of species-climate impact models under climate change. Glob. Chang. Biol. 2005, 11, 1504-1513, doi:10.1111/j.1365-2486.2005.01000.x.

44. Zhang, K.; Zhang, Y.; Tao, J. Predicting the potential distribution of Paeonia veitchii (Paeoniaceae) in China by incorporating climate change into a maxent model. Forests 2019, 10, 190, doi:10.3390/f10020190.

45. Godsoe, W.; Franklin, J.; Blanchet, F.G. Effects of biotic interactions on modeled species' distribution can be masked by environmental gradients. Ecol. Evol. 2017, 7, 654-664, doi:10.1002/ece3.2657.

46. Elith, J.; Graham, C.H.; Anderson, R.P.; Dudík, M.; Ferrier, S.; Guisan, A.; Hijmans, R.J.; Huettmann, F.; Leathwick, J.R.; Lehmann, A.; et al. Novel methods improve prediction of species' distributions from occurrence data. Ecography Cop. 2006, 29, 129-151, doi:10.1111/j.2006.0906-7590.04596.x.

47. Pecchi, M.; Marchi, M.; Burton, V.; Giannetti, F.; Moriondo, M.; Bernetti, I.; Bindi, M.; Chirici, G. Species distribution modelling to support forest management. A literature review. Ecol. Modell. 2019, 411, 108817, doi:10.1016/j.ecolmodel.2019.108817.

48. Laurente, M. Modeling the Effects of Climate Change on the Distribution of Cedrela odorata L. "Cedro" in the Peruvian Amazon. Biologist 2015, 13, 213-224.

49. Reynel, C.; Pennington, T.; Pennington, R.; Flores, C.; Daza, A. Árboles útiles de la Amazonía Peruana y sus usos; Lima, Peru, 2003; ISBN 9972-9733-1-X.

50. Reynel, C.; Pennington, T.; Pennington, R.. Árboles del Perú; Lima, Peru, 2016.

51. OSINFOR. Modelamiento espacial de nichos ecológicos para la evaluación de presencia de especies forestales maderables en la Amazonía peruana; Lima, 2013.

52. Fielding, A.H.; Bell, J.F. A review of methods for the assessment of prediction errors in conservation presence/absence models. Environ. Conserv. 1997, 24, 38-49, doi:10.1017/S0376892997000088.

53. Velazco, S.J.E.; Galvão, F.; Villalobos, F.; De Marco, P. Using worldwide edaphic data to model plant species niches: An assessment at a continental extent. PLOS ONE 2017, 12, e0186025, doi:10.1371/journal.pone.0186025.

54. Rodriguez, L.O.; Young, K.R. Biological diversity of Peru: Determining priority areas for conservation. Ambio 2000, 29, 329-337, doi:10.1579/0044-7447-29.6.329. 
55. Fajardo, J.; Lessmann, J.; Bonaccorso, E.; Devenish, C.; Muñoz, J. Combined use of systematic conservation planning, species distribution modelling, and connectivity analysis reveals severe conservation gaps in a megadiverse country (Peru). PLoS ONE 2014, 9, e114367, doi:10.1371/journal.pone.0114367.

56. Possingham, H.P.; Wilson, K.A. Protected Areas: Goals, Limitations, and Design; 2006.

57. Burnett, K.M.; Ticktin, T.; Bremer, L.L.; Quazi, S.A.; Geslani, C.; Wada, C.A.; Kurashima, N.; Mandle, L.; Pascua, P.; Depraetere, T.; et al. Restoring to the future: Environmental, cultural, and management trade-offs in historical versus hybrid restoration of a highly modified ecosystem. Conserv. Lett. 2019, 12, doi:10.1111/conl.12606.

58. Rodríguez, J.C.; Sabogal, C. Restoring degraded forest land with native tree species: The experience of "Bosques Amazónicos" in Ucayali, Peru. Forests 2019, 10, 851, doi:10.3390/f10100851.

59. Ymber, F.B. Especies Forestales Nativas Para Recuperacion de areas Degradadas en la Region Ucayali; 2014. 